\title{
Effect of Entrepreneurship policies on ind ustrialization in Selected states in South-East, Nigeria
}

\author{
Light Ikonne and Ngozi Nwogwugwu, $\mathrm{PhD}$ \\ Department of Political Science and Public Administration, Veronica Adeleke School of Social Sciences, \\ Babcock University, Ilishan-Remo, Ogun State, Nigeria \\ Correspondence email: nwogwugwun@babcock.edu.ng
}

\begin{abstract}
Nigeria is the most populous country in Africa and enormously endowed with huge mineral resources which if properly harnessed can transform the country to one of the most economically developed countries in the world. However, the formulation and implementation of development policies by successive governments in Nigeria, had not resulted in the industrialization of the country and attainment of economic development. Descriptive and inferential statistics were employed in analysis of data. The study found that entrepreneurship policies $F(1$, $133)=2.003, A d j . R^{2}=.007, P>0.05$ have no significant effect on industrialization in Abia state. It also reveals that entrepreneurship policies $F(1,120)=.082, A d j . \quad R^{2}=-.008, P>0.05$ have no significant effect on industrialization in Imo state. However, entrepreneurship policies $F(1,140)=30.062, A d j . R^{2}=.172, P<0.05$ was found to have significant effect on industrialization in Anambra state. The study recommends among others that effective implementation and constant monitoring entrepreneurship to ensure attainment of industrialization.
\end{abstract}

Keywords: Entrepreneurship policies, economic development, industrialization, SMEs

DOI: $10.7176 /$ JPID/52-06

Publication date: February $29^{\text {th }} 2020$

\subsection{Introduction}

Nigeria is naturally blessed with both material, human and entrepreneurship capabilities but the realization of the full potentials of these opportunities have been inhibited by the implementation of inappropriate and unsustainable entrepreneurship policies as these policy interventions would have stimulated entrepreneurship development but failed. As a result, indigenous entrepreneurs become distribution agents of imported products as opposed to building internal entrepreneurial capacity for manufacturing and expert services for the nation (Adebobola, 2014, Ebiringa, 2012, Thaddeus, 2012). As one of the most populous countries in Africa, Nigeria is enormously endowed with human, agricultural and huge untapped mineral resources. Despite its endowed blessings, the country has not really utilized its resources to her advantage rather the country has expiremented through successive governments administration different policies aimed at boosting the economy through industrialization.

Industrialization is about the "introduction and growth" of industries in a particular place, region or country (Obioma and Ozughalu, 2005). "A situation whereby many industries are established in different parts of the country for the production of many different types of products (Obioma and Ozughalu, 2005; Nyor and Chinge, 2014). Anyanwu et al (1997) views industrialization as a process of building up a nation's capacity to convert raw materials and other inputs to finished goods and to manufacture goods for other production or for final consumption.

Ekpo, (2005) defined industrialization as the process of "transforming raw materials, with the aid of human resources and capital goods into (a) consumers goods, (b) new capital goods which allows more consumers goods (including food) to be produced with the same human resources, and (c) social overhead capital, which together with human resources provides new services to both individuals and business". Its equally relates to development in several sectors of the economy such as manufacturing, banking, building and construction, mining and quarrying, communication, real estate (Obioma and Ozughalu, 2005) and public utilities (Ekpo, 2005).while the CBN (2002) listed the industrial sector components in Nigeria to include the manufacturing, construction, electricity, mining, water and gas industries.

According to Ogbuabor, et al (2018) Nigeria in the quest to achieve industrialization and attendant benefits such as employment generation, poverty reduction, and economic development, had pursued several industrialization policies since its independence in 1960. Industrialization plays a major role in the attainment of economic development of nations through the promotion of entrepreneurship.

In Idam (2014), entrepreneurship is seen as an emerging field of study and as an area of human endeavor, which has received increasing interest of researchers and policy makers the world over. It has equally provoked controversies over its concepts and definitions. Generally, entrepreneurship as a concept is seen not only as an 
effective means of combating unemployment, poverty and under-development in the developing nations, but also as a strategy for rapid economic development in both developed and developing nations (Schumpeter, 1934; Harper, 1991; Morris \& Lewis, 1991; Hamilton, 2000; Clausen, 2006; Praag \& Versloot, 2007).

In Nigeria, several studies have been carried out to show the on unemployment level in Nigeria (Nwogwugwu and Irechukwu 2015; Salami 2013; Thaddeus, 2012) as well as on the positive impacts of entrepreneurship policies on the problem of high unemployment rate, high level of poverty and slow economic development rate (Adejumo, 2001; Ariyo, 2005; Agboli \& Ukaegbu, 2006; Abimbola \& Agboola, 2011; Thaddeus, 2012; Salami, 2013). However, there is paucity of literature on the effect of entrepreneurship policies on industrialization. Many economies that have moved from third world to either first or second world status such as China, Indonesia and Indiaa are reputed to have done so, on the strength of the growth of their small and medium enterprises (SMEs) which had facilitated attainment of industrialization through well planned and executed entrepreneurship policies (Liu, 2003 as cited in Vladut-Severian \& Alexandru, 2014).

However, in Nigeria, such scenario has not been replicated. Nigeria has formulated and implemented several entrepreneurship policies without such policies directly translating to economic development as a result of lack of synergy between the various institutions and agencies charged with executing the policies. So far, industrialization had proved elusive to Nigeria, in spite of implementation of myriad of development policies over the years. The study therefore examined the effect of entrepreneurship policies on industrialization with a view to facilitate attainment of economic development in South East, Nigeria.

\subsection{LITERATURE REVIEW}

\subsection{Entrepreneurship policy}

There is no universally accepted definition of the term entrepreneurship (Schumpeter 1939, Stevenson \& Jarillo 1990, Gartner \& Baker 2010) due to the fact that different definitions have been put forward by scholars from various disciplines such as psychology, sociology, economics, political science and cultural studies (Ojo, 2013). Entrepreneurship is a significant and dynamic process of innovation and economic activity world over. It involves the activities of private investment, job and wealth creation, opportunities and economic development and its theory according to Hirsch and Peter (2002) has its origin from the works of Joseph Schumpeter, Richard cantillion, Max Weber and others between 1940 and 1950s (Audretsch 2012: Shane \& venkataraman, 2000; parker, 2009).

The concept of entrepreneurship has a wide range of meanings and has since its inception as an academic field of study fuelled debates questioning whether it can be taught in all disciplines (Hills, 1998). It was first used in the early 18th century by an Irish man by name Rechard Cantillon who was then living in France (Akanni, 2010). The term entrepreneurship was derived from the French word entreprendre which means to undertake. Hence, is the process of understanding, identifying and exploiting business opportunities while assuming its attendant risks (Engelhoff, 2005).

According to Joseph Schumpeter, an Australian economist, the single function which constitute entrepreneurship concept is innovation, such as: new products, new production method, new market and new forms of organization. Entrepreneurship is therefore a process which involves the creation of an innovative economic organization for the purpose of gain or growth under condition of risk and uncertainty (Dollinger, 2001 quoted in Akanni, 2010, Brinda \& Dileep, 2011).

Policy is a part of the environmental factors that supports the development of entrepreneurship of any country world over. Policy has been described Stevenson and Lundström (2001, p. 11) noted that entrepreneurship policy has become an emerging field of the economic development arena. Global attention in entrepreneurship policy has equally increased ever since. Entrepreneurship policies are the plans or courses of action, established by government in order to influence and enhance entrepreneurial decisions and actions (Audretsch, Grilo, \& Thurik, 2007; Klapper, Amit, \& Guillén, 2010).

However, in Nigeria different administrations at various periods have initiated programmes and policies aimed towards developing its entrepreneurship. Several developmental and financial strategies were employed in this process as well. Despite these efforts by the government, the programme has been unsuccessful as a result of domineering bureaucratic processes, corruption, insufficient and ineffectual infrastructural amenities (Ihugba, Odii, and Njoku 2014, Obaji \& Olugu, 2014).

However, in the light of the government's efforts to boost the economy through industrialization and to enable the private sector perform her expected role as the driver of economic development, the government which has a 
fundamental responsibility of promoting growth and development came up with policies to encourage private sector initiatives and participation.

The Small and Medium Enterprises Development Agency of Nigeria (SMEDAN) was established in 2003, to facilitate the promotion and development of Micro, Small and Medium Scale Enterprises (MSMEs) sector of the Nigerian economy (SMEDAN, 2011). The overall objective was reducing poverty through wealth and job creation to facilitate socio-economic transformation or national economic development, the Micro, Small and Medium Enterprise are perceived as engine of socio-economic transformation in both developed and developing countries. Ekwem (2011), listed the functions of SMEDAN as contained in the enabling Act of 2003 which is summarized as follows: Stimulating, coordinating and monitoring the development of the MSMEs sector, initiating and articulating policy ideas for micro, small and medium enterprises' growth and development, facilitating and promoting development programmes or initiative, support services in other to accelerate the modernization of MSME operations in the country, serving as vanguard for poverty reduction, rural industrialization, job creation and enhance sustainable livelihoods.

National Enterprise Development Programme (NEDEP) which was the centrepiece of the Government's efforts at poverty reduction and a Federal government initiative launched in 2013. The programme was expected to provide business development services, entrepreneurship training, access to affordable finance and core craft skills acquisition. One of the programme's main objective is to solve the problems of unemployment, through technical and vocational training and the empowerment of the unemployed by providing access to start-up funds.

Baba, Dickson, \& Kromtit (2014), recalled the programme was to address four major areas to combat unemployment: i). Small Scale Enterprises programme: This is for the graduate and mature unemployed people. ii). Vocational / entrepreneurship skills development programme: This is for National Open Apprenticeship, School on wheels, Waste to Wealth, Resettlement and disabled persons scheme and so forth. iii). Rural Employment Promotion Programme: Graduate Agriculture Self- Employment Programme. iv). Special public works programme:

The YouWiN Programme was established in 2011 with the collaboration of the Ministry of Finance, the Ministry of Communication Technology (CT), the Ministry of Youth Development and the Ministry of Women Affairs and Social Development which launched annual Business Plan Competition (BPC) for aspiring young entrepreneurs to showcase their business expertise, skills and aspirations to business leaders, investors and mentors in Nigeria (Tende, 2014). A major objective of the Programme is to generate jobs by encouraging aspiring entrepreneurial youths in Nigeria to develop and execute business ideas that will lead to job creation (Akpedji, 2015, YouWIN, 2013).

The Rural Finance Institution Building Programme (RUFIN) is a Loan Agreement between the Federal Government of Nigeria and the International Fund for Agricultural Development (IFAD).

The objective of this programme is to strengthen and develop and strengthen Micro Finance Banks (MFBs), other member-based Micro Finance Institutions (MFls), by enhancing the access of the rural populace to the services of these institutions in order to expand and improve agricultural productivity and Micro-Small Rural Enterprises.

The Bank of industry (BOI) has been a strategic supporter of youth innovation and entrepreneurship in Nigeria. Bank of industry Limited (BOI) according to Akingunola (2011) was established in October, 2001 following the reconstruction of Nigerian Industrial Development Bank (NIDB), Nigerian Bank for Commerce and Industry (NBCI) and National Economic Reconstruction Fund (NERFUND). The mission was to transform Nigeria's industrial sector and integrate it into the global economy by providing financial and business support services to existing and new industries in order to attain modern capabilities to produce goods that are competitive in both domestic and external markets.

A number of factors have been listed as have contributed to the ineffectiveness of the successive governments' efforts at attainment of industrialization. These factors include poor policy implementation, policy instability and inconsistency (Osotimehin, Jegede, Akinlabi and Olajide, 2012), Public sector dominance, unstable governmental system, lack of financial support from relevant agencies, corruption (Ocheni and Gemade, (2015),Adebisi and Gbegi, 2013), Poor funding; Ihugba, Odii and Njoku (2013) infrastructural decay; Okeke and Eme (2014), multiple taxation and levies (Gbandi and Amissah, (2014); Agwu and Emeti, (2014); Etuk, Etuk and Baghebo, (2014); Adebisi and Gbegi, (2013) and the high cost of doing business in Nigeria, Duru (2011). 


\subsection{Industrialization:}

Industrialization plays a significant role in the process of a country's economic development. The level of industrialization of a country enhances her productive ability to provide the needed goods and services, employment generation, poverty reduction and better standard of living of the citizenry. Amaku (2004), states that "industrialization is the mechanization of the productive process. Developing the productive capacity of a nation to process raw materials into finished products and essential services".

A situation whereby many industries are established in different parts of the region or country for the production of many different types of products (Obioma and Ozughalu, 2005; Nyor and Chinge, 2014). For instance, in Nigeria according to Ogbuabor et al (2018), industrialization is the process of transforming an economy structurally from a primarily agricultural-based or mono-cultural to a predominantly industrial based or manufacturing economy.

Industrialization leads to "large scale production of goods which are available to the consumer at much cheaper rates; saving of time and labor; considerable rise in the standard of living of the people; a variety of substitutes in consumer goods; creation of new job opportunities, leading to the removal of poverty to a great extent; and the development of new means of transportation" Simandan (2009), Ortiz, Castro, and Badillo, (2009), and Agba and Odu (2013).

Nigeria has pursued several industrialization policies since the 1960s (Audi and Mohammed, 2014; Nyor and Chinge, 2014; Tamuno and Edoumiekumo, 2012).These industrialization policies by the federal government include "the import-substituting industrialization strategy embedded in the first national development plan of 1962-1968, which focused on domestic production of manufactured goods for domestic markets (Busari, 2005); the indigenization policy of 1972 and 1977 aimed at preparing indigenous entrepreneurs for rapid industrial development; the export promotion industrialization strategy entrenched in the structural adjustment programme of 1986, which emphasized domestic production of manufactured goods for export in order to generate more foreign exchange particularly from non-oil sources to meet the country's rising import bills, mounting external debt obligations, rising fiscal responsibilities of the government, and to attend to socio economic responsibilities (Obioma and Ozughalu, 2005); the foreign private investment led industrialization strategy implemented since 1999 targeted at restoring investor's confidence and attracting massive inflow of foreign capital in the industrial sector; the small and medium enterprises development agency of Nigeria established to cater for the development of SMEs in Nigeria; and the national economic empowerment and development strategy, aimed at growing the private sector as the engine of growth for wealth creation, employment generation and poverty reduction (Okereka, 2015; Ekpo, 2014; Nyor and Chinge, 2014).

Despite the implementation of these above industrialization policies, Nigeria is still far from being industrialized (Nyor and Chinge, 2014). Ekpo (2014), identified several factors militating against industrialization in Nigeria to include: poor policy conceptualization and implementation; lack of technological capability, high cost of production resulting in non-competitiveness of Nigeria's manufactured goods in both local and international markets; concentration on light consumer goods instead of capital goods which sustains industrialization; inadequate infrastructure such as transportation, water supply, electricity supply and telecommunications; and poorly developed human capital.

Nigeria in its quest for development has many challenges impeding its journey to industrialization and attainment of economic development. Some of these challenges include: a weak raw material base since more attention is being channeled into mining following the discovery of oil, inadequate technical manpower, poor policy implementation, lack of entrepreneurship skills, and political instability arising from military interference in governance. Other factors include corruption in private and public sectors, lack of finance for industrial development activities, militancy and insceurity (Iwuagwu, 2009; Ayodeji and Balcioglu, 2010; Nwogwugwu, Alao and Egwuonwu, 2012; Chete, et al., 2014; Isiksal and Odoh, 2016).

\subsection{Theoretical Framework}

Schumpeter's Theory of Economic Development was adopted as theoretical construct for analysis of the effect of entrepreneurship policies on industrialization in this study

\section{Schumpeter's Theory of Economic Development}

Schumpeter, made significant contribution to the theory of economic development. In developing his theory, Schumpeter $(1989,1961,1934)$ argued that the innovation and technological change of any country comes from the entrepreneurs. He believed that these individuals through their innovations move the economy of any nation 
forward. Schumpeter was the leading theorist to put the human agent at the centre of the process of economic development. Schumpeter was clear about one of the economic functions of the entrepreneur as an innovator and not an imitator (Bula, 2012; Dorin and Alexandru, 2014). His view implies that entrepreneurship is acquired through the process of innovation.

Schumpeter sees the entrepreneur as an 'innovator' who transforms the market place by introducing new production method, new source of raw materials, new form of organisation and finally a new product to the market. This innovative tendency of the entrepreneur is very vital for economic development (Naude, 2013). Schumpeter's views are particularly applicable to developing countries like Nigeria where entrepreneurship and innovations need to be encouraged.

\subsection{Methodology}

The study adopted survey design, while population of study was Abia, Anambra and Imo States, selected from the South-East geo-political zone of Nigeria. Six local governments were selected, two from each of the states. The six Local governments are Aba North and Aba South, Nnewi south and Onitsha north, Orlu and owerri west Local governments. The local governments were selected because they serve as the major entrepreneurial hubs of the south-east geo-political zone of Nigeria.

\subsection{Sample size}

In determining the sample size, the researcher adopted Taro Yamane (1967) formula. A 95\% confidence level and level of maximum variability $(\mathrm{P}=0.5)$ are assumed. Where $\mathrm{n}$ is the sample size, $\mathrm{N}$ is the population size, and e is the level of precision (allowable error) that is $5 \%$ or 0.05 :

Where $\mathrm{n}$ is the sample size, $\mathrm{N}$ is the population size, and e is the level of precision (allowable error) that is $5 \%$ or 0.05 .

The Taro Yamane formula is stated below as:

$\mathrm{n}=\underline{\mathrm{N}}$

$1+\mathrm{N}(\mathrm{e})^{2}$

Where $\mathrm{n}=$ sample size; $\mathrm{N}=$ Total population of the study; e = Error of margin at $5 \%$ level or level of precision (a) (0.05), we have

$$
\begin{aligned}
& \mathrm{n}=\frac{1, \underline{514,000}}{1+514,000(0.05)^{2} .} \\
& \mathrm{n}=\frac{1,514,000}{1+3780} \\
& \mathrm{n}=399.89, \text { therefore } \mathrm{n}=400 .
\end{aligned}
$$

\subsection{Results, Analysis and Discussion}

Research question: How does entrepreneurship policies affect industrialization of the selected States of South East, Nigeria? 
Table 1: the effect of entrepreneurship policies on industrialization

\begin{tabular}{|c|c|c|c|c|c|}
\hline Abia & $\begin{array}{l}\text { Strongly } \\
\text { Agree (\%) }\end{array}$ & $\begin{array}{l}\text { Agree } \\
(\%)\end{array}$ & $\begin{array}{l}\text { Disagree } \\
(\%)\end{array}$ & Mean & SD \\
\hline $\begin{array}{l}\text { The entrepreneurship policies have facilitated relationships with banks for } \\
\text { funding of industries in my state }\end{array}$ & $70(52.2)$ & $64(47.8)$ & & 4.52 & .501 \\
\hline Entrepreneurship policies affects the establishment of SME's in my state. & $54(40.3)$ & $80(59.7)$ & & 4.40 & .492 \\
\hline $\begin{array}{l}\text { Entrepreneurship policies and programmes have provided avenue to } \\
\text { establishment of industrial clusters }\end{array}$ & $42(31.3)$ & $92(68.7)$ & & 4.31 & .466 \\
\hline $\begin{array}{l}\text { Entrepreneurship policies helped entrepreneurs to explore new market } \\
\text { opportunities and also helps to open up competition from domestic and } \\
\text { foreign bases. }\end{array}$ & $38(28.4)$ & $92(68.7)$ & $4(3)$ & 4.19 & .720 \\
\hline Imo & $\begin{array}{l}\text { Strongly } \\
\text { Agree (\%) }\end{array}$ & $\begin{array}{l}\text { Agree } \\
(\%)\end{array}$ & $\begin{array}{l}\text { Disagree } \\
(\%)\end{array}$ & Mean & SD \\
\hline $\begin{array}{l}\text { Entrepreneurship policies helped entrepreneurs to explore new market } \\
\text { opportunities and also helps to open up competition from domestic and } \\
\text { foreign bases. }\end{array}$ & $5(4.1)$ & $116(95.9)$ & & 4.04 & .200 \\
\hline Entrepreneurship policies affects the establishment of SME's in my state. & & $121(100)$ & & 4.00 & .000 \\
\hline $\begin{array}{l}\text { Entrepreneurship policies and programmes have provided avenue to } \\
\text { establishment of industrial clusters }\end{array}$ & $5(4.1)$ & $107(88.4)$ & $9(7.4)$ & 3.97 & .340 \\
\hline $\begin{array}{l}\text { The entrepreneurship policies have facilitated relationships with banks for } \\
\text { funding of industries in my state }\end{array}$ & & $115(95)$ & $6(5)$ & 3.95 & .218 \\
\hline Anambra & $\begin{array}{l}\text { Strongly } \\
\text { Agree }(\%)\end{array}$ & $\begin{array}{l}\text { Agree } \\
(\%)\end{array}$ & $\begin{array}{l}\text { Disagree } \\
(\%)\end{array}$ & Mean & SD \\
\hline $\begin{array}{l}\text { The entrepreneurship policies have facilitated relationships with banks for } \\
\text { funding of industries in my state }\end{array}$ & $81(57.4)$ & $60(42.6)$ & & 4.57 & .496 \\
\hline Entrepreneurship policies affects the establishment of SME's in my state. & $76(53.9)$ & $65(46.1)$ & & 4.54 & .500 \\
\hline $\begin{array}{l}\text { Entrepreneurship policies helped entrepreneurs to explore new market } \\
\text { opportunities and also helps to open up competition from domestic and } \\
\text { foreign bases. }\end{array}$ & $76(53.9)$ & $65(46.1)$ & & 4.54 & .500 \\
\hline $\begin{array}{l}\text { Entrepreneurship policies and programmes have provided avenue to } \\
\text { establishment of industrial clusters }\end{array}$ & $61(43.3)$ & $80(56.7)$ & & 4.43 & .497 \\
\hline
\end{tabular}

Source: Field survey, 2019

The results in table 1 above reveal that entrepreneurship policies affects industrialization in Abia state by facilitating relationships with banks for funding of industries (mean=4.52) and through the establishment of SME's (mean=4.40). Entrepreneurship policies also affects industrialization in Imo state by helping entrepreneurs to explore new market opportunities and also helps to open up competition from domestic and foreign bases (mean=4.04) as well as through the establishment of SME's (mean=4.00). In Anambra state, entrepreneurship policies affect industrialization by facilitating relationships with banks for funding of industries (mean=4.57), establishment of SME's (mean=4.54) and helping entrepreneurs explore new market opportunities and also helps to open up competition from domestic and foreign bases (mean=4.54).

Our findings on research question one, revealed that on the average, the respondents agreed that entrepreneurship policies affect industrialization in Abia state by facilitating relationships with banks for funding of industries (mean=4.52) and through the establishment of SME's (mean=4.40). Entrepreneurship policies also affects industrialization in Imo state by helping entrepreneurs to explore new market opportunities and also helps to open up competition from domestic and foreign bases (mean=4.04) as well as through the establishment of SME's (mean=4.00). In Anambra state, entrepreneurship policies affect industrialization by facilitating relationships with banks for funding of industries (mean=4.57), establishment of SME's (mean=4.54) and helping entrepreneurs explore new market opportunities and also helps to open up competition from domestic and foreign bases (mean=4.54).

Another finding of this study was that entrepreneurship policies have significant effect on industrialization in the selected states in South East, Nigeria. It is no doubt that entrepreneurship fuel the innovation and economic development of cities, states and the country at large (Porfírio, et al., 2016). It is also a known fact that entrepreneurship gives an economy better chances of improvement and industrialization. However, policies directly or indirectly affects entrepreneurial activities (Akinyemi \& Adejumo, 2018). 
Similarly, in another interview with a government official, the interviewee indicated that the Anambra state ministry of trade and commerce, small and medium enterprises (SME) department organized a three day vocational training workshop for entrepreneurs in partnership with the small and medium enterprises development agency of Nigeria (SMEDAN) which aimed at empowering individuals in the state with entrepreneurship skills, such as production of liquid soaps, perfumes, car wash, disinfectants and insecticides. The targeted beneficiaries of the programme were entrepreneurs between the ages of 20-45 years.

Industrialization influences agricultural output. Thus, an increase in the agricultural sector leads to an increase in the industrial sector which in turn brings about economic development (Adejumo, 2000; Edobor, 2013). The finding from the study therefore supports that of Castaño et al (2016) in which Entrepreneurship was found to have a positive correlation with economic growth and development. Various Nigerian government policies and programmes, according to Oliyide, (2012) and Today.ng (2018) cited in Akinyemi \& Adejumo (2018) such as the SMEDAN, the You-win and other Government Enterprise development programmes were designed to promote entrepreneurial activities by facilitating access to funds and other resources needed for SMEs. The policies and programmes are targeted towards promoting entrepreneurship to support and improve economic development and industrialization.

These policies no doubt have laudable objectives to make impactful contributions towards industrialization, as well as helping to remove constraints on entrepreneurs and expand the opportunities available to them by providing information and needed training, financial assistance, which are considered relevant to entrepreneurship development. Literature affirms that entrepreneurship policies are significant in the achievement of economic development of any nation world over. The contributions of the small and medium scale enterprises in the industrial sector to the Nigeria's Gross Domestic Product (GDP) are valued at about $37 \%$, thereby making it the second largest contributor to the Nation's GDP after the oil sector (SMEDAN, 2009).

In spite of these, the entrepreneurship policies in the selected states of the South East were found to have contributed positively to economic development in the South East, Nigeria.

\subsection{Research hypotheses test results}

Table 2 below reveals that there is a relative significant effect of demographic characteristics on industrialization in the selected states of the south-east. For Abia state, the result show that gender $(\beta=-.168, \mathrm{t}(133)=-2.072$, $\mathrm{P}<.05)$ has a negative effect on industrialization; marital status $(\beta=.292, \mathrm{t}(133)=3.653, \mathrm{P}<.05)$ and educational qualification $(\beta=.254, \mathrm{t}(133)=3.149, \mathrm{P}<.05)$ both have significant effect on industrialization, while age $(\beta=-.012$, $\mathrm{t}(133)=-.148, P>.05)$ was not found not to be significant in influencing industrialization. For Imo state, no demographic variable had significant effect on industrialization. In Anambra state, age $(\beta=.238, \mathrm{t}(140)=2.958$, $\mathrm{P}<.05)$ and educational qualification $(\beta=.453, \mathrm{t}(140)=4.928, \mathrm{P}<.05)$ had significant effect on industrialization; while marital status $(\beta=-.258, \mathrm{t}(140)=-3.082, \mathrm{P}<.05)$ had a negative influence, gender $(\beta=-.089, \mathrm{t}(133)=-1.003$, $\mathrm{P}>.05)$ had no significant influence on industrialization in the state.

Table 2: Influence of demographic variables on industrialization

\begin{tabular}{|l|r|r|r|r|r|}
\hline \multicolumn{5}{|c|}{ Influence of demographic variables on industrialization in Abia State } \\
\hline Demographic variables (independent) & \multicolumn{2}{|c|}{ Unstandardized Coefficients } & $\begin{array}{c}\text { Standardized } \\
\text { Coefficients }\end{array}$ & $\mathrm{t}$ & Sig. \\
\cline { 2 - 6 } & \multicolumn{1}{|c|}{$\mathrm{B}$} & Std. Error & Beta & 17.328 & .000 \\
\hline (Constant) & 15.139 & .874 & -.168 & -2.072 & .040 \\
Gender & -.474 & .229 & .292 & 3.652 & .000 \\
Marital Status & .781 & .214 & .254 & 3.149 & .002 \\
Educational Qualifications & .468 & .148 & -.012 & -.148 & .883 \\
Age & -.022 & .148 & & \\
\hline F(4, 133)=7.302, Adj. R2=.159 & & & & & \\
\hline
\end{tabular}




\begin{tabular}{|c|c|c|c|c|c|}
\hline \multicolumn{6}{|c|}{ Influence of demographic variables on industrialization in Imo State } \\
\hline \multirow[t]{2}{*}{ Demographic variables } & \multicolumn{2}{|c|}{ Unstandardized Coefficients } & \multirow{2}{*}{$\begin{array}{c}\begin{array}{c}\text { Standardized } \\
\text { Coefficients }\end{array} \\
\text { Beta }\end{array}$} & \multirow[t]{2}{*}{$\mathrm{t}$} & \multirow[t]{2}{*}{ Sig. } \\
\hline & $\mathrm{B}$ & Std. Error & & & \\
\hline (Constant) & 16.530 & .289 & & 57.142 & .000 \\
\hline Gender & -.109 & .122 & -.084 & -.892 & .374 \\
\hline Marital Status & -.235 & .165 & -.201 & -1.429 & .156 \\
\hline Educational Qualifications & -.086 & .074 & -.124 & -1.161 & .248 \\
\hline Age & .114 & .094 & .183 & 1.218 & .226 \\
\hline \multicolumn{6}{|l|}{$\mathrm{F}(4,120)=1.237, \operatorname{Adj} . R^{2}=.008$} \\
\hline \multicolumn{6}{|c|}{ Influence of demographic variables on industrialization in Anambra State } \\
\hline \multirow[t]{2}{*}{ Demographic variables } & \multicolumn{2}{|c|}{ Unstandardized Coefficients } & $\begin{array}{l}\text { Standardized } \\
\text { Coefficients }\end{array}$ & $\mathrm{t}$ & Sig. \\
\hline & B & Std. Error & Beta & & \\
\hline (Constant) & 14.169 & 1.141 & & 12.419 & .000 \\
\hline Gender & -.334 & .333 & -.089 & -1.003 & .318 \\
\hline Marital Status & -.855 & .277 & -.258 & -3.082 & .002 \\
\hline Educational Qualifications & .930 & .189 & .453 & 4.928 & .000 \\
\hline Age & .882 & .298 & .238 & 2.958 & .004 \\
\hline $\mathrm{F}(4,140)=8.647, \operatorname{Adj} . R^{2}=.17$ & & & & & \\
\hline
\end{tabular}

Dependent variable: Industrialization

Source: Field Survey (2019).

Table 3: Effect of entrepreneurship policies on industrialization

\begin{tabular}{|c|c|c|c|c|c|}
\hline & Sum of Squares & df & Mean Square & $\mathbf{F}$ & Sig. \\
\hline & 171.454 & 1 & 171.454 & 73.164 & .000 \\
\hline Regression & & & & & \\
\hline Residual & 923.301 & 394 & 2.343 & & \\
\hline Total & 1240.088 & 395 & & & \\
\hline \multicolumn{6}{|c|}{ Dependent Variable: Industrialization } \\
\hline \multicolumn{6}{|l|}{$\mathrm{R}=.396$} \\
\hline \multicolumn{6}{|l|}{ R Square $=.157$} \\
\hline Adjusted R Square $=.154$ & & & & & \\
\hline
\end{tabular}

Source: Field survey (2019)

Table 3 above reveals that entrepreneurship policies $F(1,394)=73.164$, Adjusted $\left.R^{2}=.154, P<.05\right)$ has a 
combined significant effect on industrialization in the three selected states of the South-East. The result further explains that entrepreneurship policies has about $15.4 \%$ (Adjusted $R^{2}=.154$ ) influence on industrialization in the selected states which is very weak. This therefore implies that there are other variables not captured in this study that have effect on industrialization of the selected states of the South-East. However, with this evidence, the null hypothesis is rejected and restated thus: entrepreneurship policies have significant effect on industrialization in the South-East, Nigeria.

Table 4: State by State breakdown of Effect of entrepreneurship policies on Industrialization in the three selected states

\begin{tabular}{|c|c|c|c|c|c|c|}
\hline $\mathbf{S} / \mathbf{N}$ & Hypotheses & $N$ & $\boldsymbol{B}$ & $\operatorname{Adj} . R 2$ & $\boldsymbol{F}$ & Sig \\
\hline & \multicolumn{6}{|c|}{ Abia State } \\
\hline & Effect of Entrepreneurship policies on Industrialization & 133 & .122 & .007 & 2.003 & .159 \\
\hline & \multicolumn{6}{|c|}{ Imo State } \\
\hline & Effect of Entrepreneurship policies on Industrialization & 120 & -.026 & -.008 & .082 & .775 \\
\hline & \multicolumn{6}{|c|}{ Anambra State } \\
\hline & Effect of Entrepreneurship policies on Industrialization & 140 & .422 & .172 & 30.062 & 0.00 \\
\hline
\end{tabular}

Dependent variable: Industrialization

Predictor variables: entrepreneurship policies

Results displayed on table 4 above reveal that entrepreneurship $F(1,133)=2.003$, Adj. $R^{2}=.007, P>0.05$ have no significant effect on industrialization in Abia state. It also reveals that entrepreneurship policies $F(1,120)$ $=.082$, Adj. $R^{2}=-.008, P>0.05$ have no significant effect on industrialization in Imo state. However, entrepreneurship policies $F(1,140)=30.062$, Adj. $R^{2}=.172, P<0.05$ was found to have significant effect on industrialization in Anambra state. The R-squared statistics as explained by the fitted model implies that about $17.8 \%$ of the total variation in the measure of industrialization in the state is explained by entrepreneurship policies. The implication is that other variables not considered in this study accounted for the remaining $82.2 \%$ of the variation.

\subsection{Conclusion}

The findings of the study support the idea that the entrepreneurship policies contribute immensely to industrialization which would facilitate economic development, especially when the enabling environment is created for the SMEs to operate. When the conducive environment is not created, or the policies are implemented in haphazard manner, they fail to attain the expected industrialization. Based on the findings, the paper concludes that entrepreneurship policies when strategically formulated and effectively implemented promotes industrialization and serves as a major instrument for attainment of economic development.

It is recommended that for both the state and the federal governments of Nigerian to succeed in her economic development vision, her citizenry especially the youths and women must be sensitized on the need to equip themselves with various entrepreneurship development skills which would eventually assist in the country's quest to become one of the most economic viable nations of the world. The government should create an enabling business environment for the needed industrialization base that is required to diversify her economy as it is a vital area to consider in the evaluation of entrepreneurship performance. Private individuals and other stake holders must equally help the government in her efforts in diversifying the economy.

However, for industrialization to be sustained in the South. -East region, the manufacturing sector must focus on the production of capital goods, develop a sustainable agricultural sector to support its industrial sector which 
will lead to a viable economy. Government should introduce policies that can attract foreign investors to invest locally which in turn leads to enhanced economic development

\section{REFERENCES}

Abimbola, O. H. \& Agboola, G. M. (2011), "Environmental factors and entrepreneurship development in Nigeria", Journal of Sustainable Development in Africa, 13(4), 166-176.

Adebisi, J. F. \& Gbegi, D. O. (2013), "Effects of tax avoidance and tax evasion on personal income tax administration in Nigeria". American Journal of Humanities and Social Sciences, Vol 1(3): 125 - 134.

Adejumo, G. (2001), "Indigenous entrepreneurship development in Nigeria: Characteristics, problems and prospects. Advances in Management": Journal of Department of Business Administration, 2(1), 112-122.

Adejumo, G. (2000), "Indigenous entrepreneurship development in Nigeria. Characteristics, Problems and Prospects", Journal of Department of Business Administration, University of Ilorin, Nigeria.

Agba, A.M.O. and Odu, E. (2013), "Globalization and the challenge of industrialization in developing nations: The Nigeria experience", IOSR Journal of Humanities and Social Science,12(4),41-47.

Agboli, M. \& Ukaegbu, C. C. (2006), "Business environment and entrepreneurial activity in Nigeria: Implications for industrial development”. Journal of Modern African Studies. 44(1), 1-30.

Agwu, M. O. \& Emeti, C. I. (2014), "Issues, challenges and prospects of small and medium scale enterprises (SMEs) in Port Harcourt City, Nigeria”. European Journal of Sustainable Development, 3(1), 101 - 114.

Akpedji, G. (2015, November 07), "YouWin awardees protest non-payment of second third trenches", Guardian newspaper, Retrieved on 9th November from http://www.ngrguardiannews.com.

Ashmore, M., C. (1989), “The Power of Entrepreneurship Vision”, Vocational Education Journal. (64) 186.

Audi, M.S., Mohammed, A. (2014), "Industrialization and Sustainable Development in Nigeria", The International Journal of Social Sciences and Humanities Invention, 1(3), 142-154.

Audretsch, D. B., Grilo, I., \& Thurik, A. R. (2007), "Explaining entrepreneurship and the role of policy: A framework". In The handbook of research on entrepreneurship policy (pp. 1-17). Edward Elgar Publishing.

Ayodeji, A.R. and Balcioglu, H. (2010), "Financing industrial development in Nigeria: A case study of the small and medium enterprises in Kwara State", Global Journal of Management and Business Research, 10(3), 46-60.

Baba, S, Dickson V, Kromtit M. (2014), "Entrepreneurship and employment generation in Nigeria a case study, National Directorate of Employment (NDE). 6(2), 40-58.

Bula, H.O. (2012). Evolution and theories of entrepreneurship: A critical review on the Kenyan perspective, International Journal of Business and Commerce, 1(7), 81-96.

Busari, D.T. (2005), Foreign capital, globalization and the challenges of industrialization in Nigeria. In: The Challenges of Industrialization: A Pathway to Nigeria becoming a Highly Industrialized Country in the Year 2015. Ibadan: Nigerian Economic Society. P521-551.

Chete, L.N., Adeoti, J.O., Adeyinka, F.M., Ogundele, O. (2014), Industrial Development and Growth in Nigeria Lessons and Challenges, Learning to Complete, Working Paper No. 8.

Dorin, C. \& Alexandru, G.S. 2014. Dinamics of the entrepreneurship concept. Literature review. University of Timisoara, Romania: Finance department, Faculty of Economics and Business Administration West.

Duru, M. (2011). Entrepreneurship opportunities and challenges in Nigeria. Business and Management Review 1(1): 41-48. 
Ebiringa, O. T. (2012). Entrepreneurship Venturing and Nigerian's Economic Development: The Manufacturing Sector in Focus., Int. J. Buss. Mgt. Eco. Res. 2(6), 2011, 376-381.

Ekwem, I. (2011), "Small and Medium Scale Enterprises Development in Nigeria: Constraints and Policy Options" (Doctoral dissertation, Stellenbosch: Stellenbosch University).

Ekpo, U. N. (2014), "Nigeria industrial policies and industrial sector performance: Analytical exploration". IOSR Journal of Economics and Finance, 3(4), 1-11.

Etuk, R. U, Etuk, G. R. \& Baghebo, M. (2014), "Small and medium scale enterprises (SMEs) and Nigeria's economic development”. Mediterranean Journal of Social Sciences, Vol. 5(7), 656 -662.

Gbandi, E. C. \& Amissah, G. (2014), "Financing options for small and medium enterprises (SMEs) in Nigeria". European Scientific Journal, 10(1), 327-340

Harper, M. (1991), “The role of enterprise in poor countries”, Entrepreneurship, Theory and Practice, 15(4), 7-11.

Idam, L.E. (2014), "Entrepreneurship development in Nigeria: A review". Journal of Business and Management, vol. 16, Issue 1, 01-07.

Ihugba, O.A., Odii, A., and Njoku, A., (2014), "Theoretical Analysis of Entrepreneurship Challenges and Prospects in Nigeria", International Letters of Social and Humanistic Sciences, 5, p. 21-34.

Isiksal, A.Z., Odoh, J.C. (2016), "Impact of industrialization in Nigeria”, European Scientific Journal, 12(10), 328-339.

Iwuagwu, O. (2009), "Nigeria and the challenge of industrial development: The new cluster strategy", African Economic History, 37, 151-180.

Klapper, L., Amit, R., \& Guillén, M. F. (2010), Entrepreneurship and firm formation across countries. In International differences in entrepreneurship (pp. 129-158). University of Chicago Press.

Moghimi, M. (2008), Stimulating entrepreneurial development. Entrepreneur Magazine.1 (2), 4-8.

National Bureau of Statistics Nigeria (2017), http://www.nigerianstat.gov.ng

Naude, W. A. (2013), "Entrepreneurship and Economic Development: Theory, Evidence and Policy", IZA Discussion Paper No. 7507, University of Maastricht, Germany.

NEDEP (2014). National entrepreneurship development programme: NEDEP- Release 1.0. http://www.nac.org.ng/NEDEP.pdf.

Nwogwugwu, N., Alao O. E. and Egwuonwu, C. (2012). Militancy and Insecurity in the Niger Delta: impact on the inflow of foreign direct investment to Nigeria. Kuwait Chapter of Arabian Journal of Business and Management Review, 2(1), pp. 23 - 37. Accessed from http://arabianjbmr.com/pdfs/KD VOL 2 1/3.pdf

Nwogwugwu, N. and Irechukwu, G. N (2015). Socio-Political Implications of Youth Unemployment on Nigeria's Economic Development. IOSR Journal of Economics and $\quad$ Finance (IOSR-JEF) 6(4.I), pp. 27-34. DOI: $10.9790 / 5933-06412734$.

Nyor, G.A., Chinge, A.D. (2014), the impacts of industrial policies on the manufacturing sector in Nigeria: An assessment. Research on, Humanities and Social Sciences, 4(21), 111-120.

Obaji, N. O. \& Olugu, M. U. (2014). The role of government policy in entrepreneurship development, 2(4), 109115. http://doi.org/10.11648/j.sjbm.20140204.12.

Obioma, E.C. and Ozugahalu, U.M. (2005). Industrialization and economic development: A review of major conceptual and theoretical issues. In: The Challenges of Industrialization: A Pathway to Nigeria becoming a Highly Industrialized Country in the Year 2015 (pp. 63-97). Ibadan: Nigerian Economic Society. 
Ocheni, S. I. \& Gemade, T. I. (2015). Effects of multiple taxation on the performance of small and medium scale business enterprises in Benue State, International Journal of Academic Research in Business and Social Sciences, Vol. 5 (3),

Ogbuabor, J. E., Anthony, O., Charles, N. A., Josaphat, U. O and Charles, O. M. (2018). Quest for Industrialization in Nigeria: The Role of the Development Bank of Nigeria, International Journal of Economics and Financial Issues, 8(3), 23-28.

Okeke, M. I. \& Eme O. I. (2014). Challenges facing entrepreneurs in Nigeria. Singaporean Journal of Business Economics and Management Studies, 3 (5), 18-34

Okereka, O. P. (2015). the national economic and development strategy (NEEDS): Its implications for human resources development and management in Nigeria, Journal of Resources Development and Management, 12, $32-35$.

Ortiz, C.H., Castro, J.A. and Badillo, E.R. (2009), Industrialization and growth: Threshhold effects of technological integration. Cuadernos de Economía, 28(51), 75-97.

Osotimehin, K. O; Jegede, C. A; Akinlabi, B. H. \& Olajide, O. T. (2012), "An evaluation of the challenges and prospects of micro and small scale enterprises development in Nigeria". American International Journal of Contemporary Research, 2 (4), 174 - 185.

Praag, C.M.V. \& Versloot, P.H. (2007), “What is the value of entrepreneurship?” IZA Discussion Paper No. 3014. Retrieved from ftp.iza.org/dp3014pd.

Salami, C. G. E. (2013), "Youth unemployment in Nigeria: A time for creative intervention", International Journal of Business and Marketing Management, 1 (2), pp. 18-26.

Sambo, A. (1996), "The state of bureaucracy under military rule", In Adebayo, N. (Ed). The quest for democratization: military governance and trade unionism, Lagos: Friedrich Ebert Foundation.

Sevastapulo, D. (2014), “Delta Blues”. The Financial Times, 23, 01, 14.

Schumpeter, J. A., (1989), The Theory of Economic Development, Cambridge (Mass): Harvard University Press.

Schumpeter, J.A. (1961), The Theory of Economic Development. New York: Oxford University Press.

Schumpeter, J. A. (1934). "The theory of economic development”. Cambridge, MA, US: Harvard University Press.

Simandan, D. (2009). “Industrialization”. In: Kitchin, R., Thrift, N., (eds). International Encyclopedia of Human Geography. 05, pp. 419-425. Oxford: Elsevier.

SMEDAN (2011). Annual report. Hard Copy Distributed by SMEDAN

Stevenson, 1. \& Lundström, A (2001), "Patterns and trends in entrepreneurship/SME policy and practice in ten economies". Swedish Foundation for Small Business Research.

Storey, D. J. (2008), “Entrepreneurship and SMEs Policies”. Warwick Business School: World Entrepreneurship Forum.

Tamuno, S.O., Edoumiekumo, S.G. (2012), "Industrialization and trade globalization: What hope for Nigeria?" International Journal of Academic Research in Business and Social Sciences, 2(6), 157-170.

Tende, S. B. A. (2014). "Government Initiatives toward Entrepreneurship Development in Nigeria”, 8(1), 109120.

Thaddeus, E. (2012), "Perspectives: entrepreneurship development \& growth of enterprises in Nigeria". Entrepreneurial Practice Review, 2(2), 31-35. 
Vladut-Severian, I. \& Alexandru, N. (2014), "Entreprenurship, support of the economic changes in China", The USV annals of economics and public Administration, 14(2),

YOUWIN (2015). https://www.youwin.org.ng/success-stories/.

YouWIN (2013). Youth enterprise with innovation in Nigeria. Retrieved from http://www.youwin.org.ngZhou D. (2012), Chinese Entrepreneurs Go Global. Technology Innovation Management Review. (February 2012: Technology Entrepreneurship):28-31 http://timreview.ca/user/155/article. 